20. Guillain-Barré syndrome - El Salvador. WHO. Emergencies preparedness, response. - Disease Outbreak News. - 21 January 2016.

21. Emergencies preparedness, response. WHO involvement in Zika R\&D 8 February 2016. - www.who.int/csr/research-anddevelopment/v_d_zika_involvement/en/

22. WHO. Media centre WHO Director-General summarizes the outcome of the Emergency Committee on Zika WHO statement on the first meeting of the International Health Regulations (2005) Emergency Committee on Zika virus and observed increase in neurological disorders and neonatal malformations. - 1 February 2016.

\section{PROBLEMS OF ZIKA VIRUS DISEASE IN THE WORLD}

M.A. Andreychyn, N.H. Zavidniuk, N.A. Nychyk

SUMMARY. The latest information on the relevance of the infection, its etiology, pathogen sources and ways of transmission, pathogenesis, clinical manifestations, the possibility of fetal microcephaly, specific diagnostic algorithm, nonspecific therapeutic and preventive measures are summarized. It is indicated that antiviral therapy and vaccines have not been developed yet. Key words: Zika virus, flaviviruses, Zika virus disease, mosquitoes Aedes genus, microcephaly.

Отримано 9.03.2016 р.

\title{
ФАРМАКОЕКОНОМІЧНИЙ АНАЛІЗ СТРАТЕГІЙ ДІАГНОСТИКИ ГОСТРИХ ВІРУСНИХ ІНФЕКЦІЙ: ОПЕРАЦІЙНІ ХАРАКТЕРИСТИКИ, МЕТОДИ ТА ПРИКЛАД ОЦІНКИ
}

\author{
Національна медична академія післядипломної освіти ім. П.Л. Шупика, м. Київ
}

У роботі наведено науковий підхід до оцінки стратегій діагностики гострих вірусних інфекцій, який базується на принципах фрармакоекономічної науки. Вперше визначені основні поняття, операційні характеристики, що використовуються в такому аналізі, та наведено конкретний приклад його використання в медичній практиці. Можливість впровадження такого аналізу в роботу організаторів та експертів охорони здоров'я, лікарів і завідуючих медичними лабораторіями дозволить підвищити ефективність роботи будь-якого лабораторного підрозділу або лабораторій різних фрорм власності.

Ключові слова: гостра вірусна інфекція, діагностична стратегія, фрармакоекономіка, метод «витрати-ефективність», аналітична модель.

В 1919 р. відомий швейцарський психіатр Ернст Блейлер у своїй книзі «Аутичне недисципліноване мислення в медицині та як його подолати» сорормулював основне правило для прийняття рішень у медицині в умовах невизначеності: «Ймовірності шкоди та користі медичних технологій повинні бути збалансовані по відношенню до їх вартості» [1]. Це точна фрормула прийняття оптимального рішення при виборі стратегій діагностики та лікування практичним лікарем, який стикається з діагностичним ризиком, не знаючи, чи є пацієнт насправді хворим, і терапевтичним ризиком, не знаючи, чи буде ефрективною терапія. Така характеристика також обумовлює оптимальний вибір критерію ефрективності або корисності для діагностичного тесту, результати якого визначаються експертом, що приймає рішення.

Систематичне поєднання Блейлером корисності, шкоди та їх ймовірностей звичайно апелює до економістів, оскільки саме економіка $€$ наукою про поведінку в ситуаціях, в яких люди повинні вибирати між недосконалими альтернативами в умовах певних обмежень. Неможливо вибрати одну медичну стратегію або технологію, не відмовляючись від іншої при обмежених 
можливостях, таких як час або фрінанси. За останні 100 років економісти розробили безліч теорій про те, як люди приймають раціональні рішення. Вони розрізняють ситуації, в яких наслідки дій є детермінованими, і ситуації, в яких природа «грає в кості». Економічні теорії прийняття рішень в умовах визначеності та невизначеності $€$ універсальними і мають широке застосування. Так, саме медицина є однією з таких галузей, де економічні теорії прийняття рішень можуть бути використані особливо продуктивно.

Сьогодні, майже через сто років з моменту виходу книги Блейлера, в медицині та фармакології широко використовується поняття «раціонального застосування лікарських засобів», яке включає в себе три тісно пов'язані складові: клінічну ефективність, безпечність та економічну ефективність медичних технологій.

Дослідженням останнього аспекту займається фрармакоекономічний аналіз (ФА), метою якого є економічна оцінка ефективності використання ресурсів охорони здоров'я, спрямованих на фрармакотерапію, інші медичні та фрармацевтичні послуги [2, 3]. Застосування ФА в лабораторній практиці обґрунтовано в тих випадках, коли виникає питання в порівнянні двох і більше діагностичних технологій та вибору більш доцільної (прийнятної) технології лабораторної діагностики з урахуванням ії ефективності та вартості. 3 недавнього часу такий вид аналізу також знайшов своє місце в клінічній лабораторній діагностиці, а також в діагностиці інфекційних захворювань. Підтвердженням цьому служать роботи з економічного обґрунтування доцільності використання методів проточної цитометрії, мультиплексної ПЛР та інші [4-8].

Серед методів ФА найбільш часто використовується метод «витрати - ефективність» [2]. Він дозволяє розрахувати показники співвідношення витрат до ефективності та показник приросту витрат на одиницю ефективності кожної діагностичної технології, чи це класичні вірусологічні методи виділення, ідентифрікації та культивування вірусів в умовах in vitro та in vivo чи серологічні (імуноферментний аналіз), молекулярногенетичні (метод полімеразної ланцюгової реакції) та експрес-методи дослідження (прості/швидкі тести).

3 метою підвищення якості лабораторної діагностики та скорочення витрат на додаткові діагностичні процедури вважається доцільним застосування ФА при виборі не тільки методу етіологічної діагностики, але й комплексної стратегії діагностики найбільш актуальних збудників вірусних інфекцій людини з урахуванням динаміки розвитку інфекційного процесу та характеру перебігу: гострого, підгострого та хронічного. Гострі вірусні інфекції починаються раптово і характеризуються короткочасним перебігом (наприклад, грип). Інколи вони можуть тривати до 3 міс. Підгострі інфекції розвивають- ся повільно і тривають від 3 до 6 міс. Хронічні інфрекції мають тривалий перебіг, продовжуються більше 6 міс., збудник дуже довго перебуває в клітинах, тканинах і органах (ВІЛ-інфекція) [9]. Цілком зрозуміло, що діагностика гострих вірусних інфекцій вимагає швидкого визначення збудника, що може бути здійснене з використанням різних діагностичних стратегій - комбінацій різних технологій визначення збудника, зокрема імуносрерментного аналізу, методу полімеразної ланцюгової реакції або простих/швидких тестів.

Впровадження методології проведення ФА таких стратегій перш за все вимагає визначення та пояснення основних термінів і характеристик, які будуть використовуватися. Такими характеристиками $€$ поширеність і захворюваність, ймовірність захворювання, чутливість й специфрічність діагностичного тесту, витрати на діагностику та її очікувана ефективність.

\section{Основні поняття}

Технологія (метод) етіологічної діагностики - це сукупність дій, які спрямовані на визначення етіологічного агента інфрекційного захворювання з використанням певних підходів та реагентів.

Алгоритм етіологічної діагностики - це послідовність дій лікаря для визначення етіологічного агента 3 використанням певної діагностичної технології.

Діагностична стратегія - сукупність запланованих дій, завданням яких $є$ ефективне використання наявних людських і фінансових ресурсів для визначення етіологічного агента інфекційного захворювання за певними діагностичними алгоритмами.

Фармакоекономіка - це наука, що вивчає у порівняльному аспекті показники діагностичної, профілактичної та терапевтичної ефективності, безпечності, якості життя, а також відповідних витрат при альтернативних медичних технологіях з метою раціонального використання коштів охорони здоров'я й суспільства для максимального задоволення потреб пацієнта. За визначенням Міжнародного товариства фрармакоекономічних досліджень (International Society for Pharmacoeconomics and Outcomes Research - ISPOR), фрармакоекономіка - це наукова дисципліна, яка оцінює повну вартість орармацевтичних препаратів, обслуговування і програм для медичної допомоги. Вона зосереджується на терапевтичних, економічних і гуманістичних аспектах медичної допомоги для профілактики, діагностики, лікування захворювань. Фармакоекономіка забезпечує інфрормацією для оптимального розподілу ресурсів охорони здоров'я [10-13].

Фармакоекономічний аналіз - це порівняльне вивчення двох і більше медичних технологій (схем профрілактики, діагностики, лікування) за показниками витрат та результатів терапії. Принципи й терміни, 


\section{ОГЛЯДИ ТА ЛЕКЦІї}

що стосуються ФА, прийнято ISPOR, яке координує у співпраці з ВООЗ наукові та прикладні напрями фрармакоекономіки. У світовій практиці використовують такі основні методи ФА:

- «вартість-ефрективність» (cost-effectiveness) - системний метод порівняння двох і більше альтернативних медичних технологій, коли вимірюють показники витрат і результатів лікування кожної 3 них;

- «мінімізація вартості» (cost-minimization) - коли результати лікування оцінюють аналогічно еквівалентно, що дозволяє порівняти витрати для вибору дешевшої альтернативної медичної технології;

- «вартість-користь» (cost-utility) - користь як ефективність лікування аналізують на основі суб'єктивної оцінки хворим якості життя (фрізичного, психологічного, соціального фрункціонування) при використанні альтернативних схем лікування; при цьому порівнюють показники якості життя (за спеціальними опитувальниками) та визначають кількість років життя, стандартизованих за якістю, з обчисленням індексу QALYs (Quality Adjusted Life Years);

- «вартість-вигода» (cost-benefit) - складніший аналіз, коли витрати і вигоди медичних технологій обчислюють лише у фрінансових показниках, оцінюючи збережені кошти внаслідок зменшення днів непрацездатності, тривалості стаціонарного лікування; цей метод застосовують для оцінки вигоди при щепленнях, ранній діагностиці, профрілактиці захворювань;
- «вартість захворювання» (cost of illness) - розрахунок усіх прямих і непрямих (середніх) витрат на діагностику та лікування захворювання на рівні держави чи регіону з метою визначення структури й тенденцій використання коштів та оптимізації пріоритетів фрінансування в охороні здоров'я [14].

Операційні характеристики діагностичних тестів

Для характеристики інформативності діагностичних методів дослідження служать об'єктивні параметри, іменовані операційними характеристиками [15].

До найважливіших операційних характеристик методу діагностики належать:

- діагностичний спектр (р),

- чутливість (Se, sensitivity),

- специфрічність (Sp, specificity).

До допоміжних критеріїв інформативності належать:

- точність (Ac, accuracy),

- прогностичність позитивного результату (positive predictive value, PPV),

- прогностичність негативного результату (negative predictive value, NPV).

Простим інструментом для визначення операційних характеристик методу діагностики є таблиця спряженості $2 \times 2$, в якій можливі результати діагностики (позитивний або негативний), відповідають можливим станам здоров'я пацієнта (наявність або відсутність захворювання) (табл. 1).

Таблиця 1

Таблиця спряженості 2×2

\begin{tabular}{|l|l|l|l|}
\hline \multirow{2}{*}{ Результат тесту } & \multicolumn{2}{c|}{ Захворювання } & \multirow{2}{*}{ Сума } \\
\cline { 2 - 3 } & \multicolumn{1}{|c|}{ наявне } & \multicolumn{1}{c|}{ відутнє } & $\mathrm{a}+\mathrm{b}$ \\
\hline Позитивний & $\mathrm{a}$ & $\mathrm{b}$ & $\mathrm{c}+\mathrm{d}$ \\
\hline Негативний & $\mathrm{c}$ & $\mathrm{d}$ & $\mathrm{n}=\mathrm{a}+\mathrm{b}+\mathrm{c}+\mathrm{d}$ \\
\hline В цілому & $\mathrm{a}+\mathrm{c}$ & $\mathrm{d}$ & \multicolumn{2}{|c|}{} \\
\hline
\end{tabular}

a - кількість дійснопозитивних результатів,

c - кількість хибнонегативних результатів,

$\mathrm{a} / \mathrm{n}$ - відсоток виявлення,

$(\mathrm{a}+\mathrm{c}) / \mathrm{n}-$ діагностичний спектр $(\mathrm{p})$,

$\mathrm{d} /(\mathrm{b}+\mathrm{d})$ - специсрічність діагностичного тесту (Sp),

$\mathrm{a} /(\mathrm{a}+\mathrm{b})$ - прогностичність позитивного результату (PPV),

\section{Діагностичний спектр}

У ФА стратегій діагностики вірусних інфекцій під діагностичним спектром розуміється частота (ймовірність) виявлення збудників-мішеней для даного тесту серед усього етіологічного спектра вірусів, виявлених у протестованих пацієнтів. Так, діагностичним спектром певного тесту або тест-системи, визначеного для певного періоду, можуть бути показники поширеності b - кількість хибнопозитивних результатів,

d - кількість дійснонегативних результатів,

$(a+b) / n$ - частка позитивних результатів діагностики,

$\mathrm{a} /(\mathrm{a}+\mathrm{c})$ - чутливість діагностичного тесту (Se),

$(\mathrm{a}+\mathrm{d}) / \mathrm{n}$ - точність діагностики,

$\mathrm{d} /(\mathrm{c}+\mathrm{d})$ - прогностичність негативного результату (NPV).

захворювання. Поширеність, як і захворюваність, визначають як співвідношення:

$$
\frac{\text { кількість випадків }}{\text { кількість населення, що підлягає ризику }}
$$

В той час як захворюваність представляє собою потік, поширеність $€$ накопичувальною характеристикою, що демонструє кількість хворих осіб на кожні 1000 або 
100 тис. населення за певний проміжок часу. Захворюваність визначається кількістю осіб, що захворіли, на 1000 або 100 тис. населення, протягом певного періоду часу. Накопичення хворих осіб (поширеність) пропорційно пов'язане із потоком (захворюваністю) через середню тривалість захворювання за незмінності інших умов:

Середня тривалість захворювання $=\frac{\text { Поширеність }}{\text { Захворюваність }}$

Ілюстрацією цього може стати співвідношення між об'ємом рідини в резервуарі і швидкістю потоку рідини в одиницю часу. Таке відношення дорівнює середньому часу перебування молекули рідини в резервуарі (мал. 1) [16].

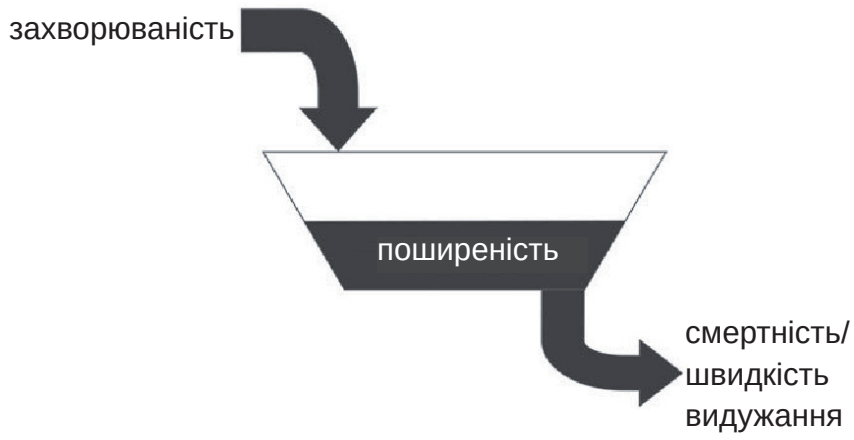

Мал. 1. Схематичне уявлення про поширеність і захворюваність.

Для хронічних захворювань, таких як ВІЛ-інфекція, гепатит С тощо, і які тривають протягом багатьох років, поширеність значно перевищує захворюваність. На відміну від цього, гострі захворювання, такі як грип, мають коротку середню тривалість, тому для них показник захворюваності протягом одного року $є$ набагато вищим, ніж рівень поширеності, визначений за той самий період.

Показник поширеності захворювання також називають апріорною ймовірністю захворювання, яку визначають за ретроспективними даними, з особистого досвіду, офріційного реєстру, або з більш загальних літературних джерел.

Інколи в медичній літературі також використовується термін ризик, що вказує на ймовірність захворювання, але це невдале використання даного терміну, оскільки загальне використання ризику в економіці пов'язане із невизначеністю, яка співвідноситься 3 ймовірністю настання можливих результатів.

чутливість і специфрічність

Під чутливістю тесту розуміють показник, який характеризує його здатність виявляти максимальну кількість дійснопозитивних зразків, а під специярічністю - здатність тесту визначати тільки той збудник, для визначення якого він призначений, що характеризує виявлення мінімальної кількості хибнопозитивних зразків. Іншими словами, чутливість тесту - це ймовірність отримання дійснохибнопозитивного результату діагностики з усіх позитивних зразків, а специфічність тесту - ймовірність дійснонегативного результату з усіх негативних. Чутливість характеризує, таким чином, дискримінаційну здатність тесту стосовно виявлення хворих пацієнтів, а специфрічність - здорових. Імовірність перебування у стані здоров'я, зазначеному тестом, називається прогностичною цінністю тесту. Ми розрізняємо дві форми прогнозних значень, позитивних і негативних.

Точність (Ac) - це частка правильних результатів тесту (тобто сума істинно позитивних й істинно негативних результатів) серед всіх обстежених пацієнтів.

Таким чином, точність показує, скільки всього правильних результатів отримано в ході застосування даного методу дослідження. Іноді цей критерій називають показником діагностичної ефективності і позначають як De (diagnostic efficiency).

Точність діагностичного методу залежить:

- від самого методу,

- використовуваного обладнання,

- обраного критерію патології,

- популяції, до якої цей тест застосовується.

Раніше «якість», точність діагностичних досліджень оцінювали шляхом порівняння результатів явно хворих людей і явно здорових добровольців. Природно, що результати відображали виражені відмінності між групами. Для реальної практики результати таких досліджень часто виявляються мало застосовними, оскільки в прихованих випадках хвороби дають випадкову «ймовірність» наявності хвороби, а метою діагностичних досліджень часто $€$ розпізнавання саме неявних симптомів захворювання.

Крім цього, з практичної точки зору, для оцінки результатів дослідження інтерес представляє ймовірність збігу укладення з остаточним діагнозом. Для цих цілей оцінюються показники прогностичності.

Так, для правильного розуміння діагностичної ефективності методів дослідження важливу роль відіграють критерії апостеріорної ймовірності - прогностичність позитивного і негативного результатів. Саме ці критерії показують, яка ймовірність захворювання (або його відсутності) при відомому результаті дослідження. Неважко зрозуміти, що апостеріорні показники мають більше значення, ніж апріорні.

Прогностична цінність або прогностичність

Прогностична цінність (predictive value) тесту ймовірність наявності захворювання за умови відомого результату діагностичного дослідження (тесту), (роз- 


\section{ОГЛЯДИ ТА ЛЕКЦІї}

раховується на підставі даних про чутливість і специорічність).

Прогностичність позитивного результату (positive predictive value, PPV) - це ймовірність захворювання при позитивному (патологічному) результаті діагностичного дослідження (тесту), пропорція істинно позитивних результатів серед всіх позитивних значень тесту.

Прогностичність негативного результату (negative predictive value, NPV) - імовірність відсутності захворювання при негативному (нормальному) результаті діагностичного дослідження.

Прогностична цінність - це характеристика не тільки самого методу. Вона залежить як від його чутливості і специфічності, так і від поширеності захворювання в досліджуваній популяції, тобто частки осіб з досліджуваним захворюванням у певній популяції в даний момент часу. Поширеність - апріорна (або передтестова) ймовірність, тобто це ймовірність виявлення хвороби до того, як стали відомі результати дослідження.
Чим більш чутливим є тест, тим вище прогностична цінність його негативного результату (тобто зростає впевненість лікаря в тому, що негативні результати дослідження відкидають наявність захворювання). Навпаки, чим тест є більш специфрічним, тим вище прогностична цінність його позитивного результату (тобто лікар може з більшою впевненістю вважати, що позитивні результати підтверджують передбачуваний діагноз). Оскільки поширеність захворювання впливає на прогностичну цінність діагностичного методу, остання неминуче залежить і від умов його виконання. Якщо позитивні результати навіть високоспецифічного методу отримані в популяції з низькою ймовірністю захворювання, то вони виявляться переважно хибнопозитивними.

Абсолютні значення можна замінити відносними частотами або ймовірностями, при чому сума ймовірностей «хворого стану» та «здорового стану» як несумісних подій дорівнює одиниці (табл. 2).

Таблиця 2

Таблиця спряженості 2×2

\begin{tabular}{|c|c|c|c|}
\hline \multirow{2}{*}{ Результат тесту } & \multicolumn{2}{|c|}{ Захворювання } & \multirow{2}{*}{ Сума } \\
\hline & наявне & відсутнє & \\
\hline Позитивний & $\mathrm{p} * \mathrm{Se}$ & $(1-p)^{\star}(1-S p)$ & $p \star S e+(1-p)^{\star}(1-S p)$ \\
\hline Негативний & $\mathrm{p}^{\star}(1-\mathrm{Se})$ & $(1-p)^{\star} S p$ & $p^{\star}(1-S e)+(1-p)^{\star} S p$ \\
\hline В цілому & $p$ & $1-p$ & 1 \\
\hline
\end{tabular}

p - діагностичний спектр,

$\mathrm{Se}$ - чутливість, або частка дійснопозитивних результатів серед всіх випадків захворювання,

(1-Se) - частка хибнонегативних результатів серед всіх випадків захворювання,

$\mathrm{Sp}$ - специфічність, або частка дійснонегативних результатів серед всіх випадків відсутності захворювання, (1-Sp) - частка хибнопозитивних результатів серед всіх випадків відсутності захворювання.

Якщо зробити перетворення відповідно до таблиці єдності значення:

$$
P P V=\frac{a}{a+b},
$$

то у підсумку отримаємо вираз на основі теореми Байєса [16]:

$$
P P V=\frac{p * S e}{p * S e+(1-p) *(1-S p)}
$$

Відповідно, для NPV буде отримано:

$$
N P V=\frac{1-p * S e}{p *(1-S e)+p *(1-S p)}
$$

Таким чином, на основі теореми Байєса прогностична цінність залежить від поширеності збудника, чутливості та специорічності діагностичного тесту, на основі чого можна зробити такі висновки:

- оскільки прогностична цінність залежить від рівня поширеності збудника, вона також залежить від цільової групи населення для діагностичного тесту. Чим вище показник поширеності, тим вище позитивна прогностична цінність тим нижче негативна прогностична цінність тесту;

- чим більшою є чутливість діагностичного тесту, тим кращою є його негативна прогностична цінність (тобто тим більше впевненим може бути лікар, що негативний результат тесту насправді вказує на відсутність захворювання).

Очікувана корисність або ефективність діагностичних тестів

Під одиницею ефрективності або корисності діагностичної технології, з точки зору лабораторної діагностики, розуміється виявлення кожного збудника або підтвердження його відсутності - дійснопозитивний чи дійснонегативний результат діагностики.

Вирішальним $є$ визначення очікуваного результату EU елементарної фрункції корисності $U\left(H_{v}^{\times}\right)$за правилом Джона фон Неймана і Оскара Моргенштерна [17]: 


$$
\begin{aligned}
& E U(x) \equiv E\left[U\left(H_{\mathbf{v}}^{\mathbf{\times}}\right)\right]= \\
& =p_{1} U\left(H_{1}^{\times}\right)+p_{2} U\left(H_{2}^{\mathbf{x}}\right)+\cdots+p_{y} U\left(H_{y}^{\mathbf{\times}}\right)=\sum_{y=1}^{Y} p_{y} U\left(H_{y}^{\mathbf{\times}}\right),
\end{aligned}
$$

де очікувана корисність $\mathrm{EU}(\mathrm{x})$ від дій $x \in$ сумою добутків початкових корисностей $U$ від $y$ наслідків $H$, пов'язаних з цими діями, на їх відповідні ймовірності.

\section{Методологія проведення ФА}

Основою дослідження $€$ визначення показників, що впливають на есрективність діагностики гострих вірусних інорекцій, витрат при використанні кожної стратегії та які використовуються при проведенні ФА з допомогою методу «витрати - ефективність». У розрахунках використовують дані ефрективності та витрат 3 метою визначення коефіцієнта «витрати-ефективність» діагностичної технології - вартості одиниці ефективності, представленої порівнюваними технологіями (4).

$$
C E R=\frac{\operatorname{Cost}_{i}}{E f_{i}},
$$

\section{де}

CER - коефріцієнт «витрати-ефективність»;

Cost $_{\text {i }}$ - витрати на діагностичну технологію (i), у.о.;

$\mathrm{Ef}_{\mathrm{i}}$ - показник ефрективності діагностичної технології (i), од.

В оцінці також використовують інкрементальний метод «витрати-ефективність», що визначає вартість додаткової одиниці ефективності, що надається більш есрективною технологією. Результатом розрахунків за таким методом стає визначення інкрементального коефріцієнта «витрати-еорективність» ICER (5):

де

$$
I C E R=\frac{\operatorname{Cost}_{j}-\text { Cost }_{i}}{E f_{j}-E f_{i}},
$$

ICER (або $\triangle \mathrm{CER}$ ) - інкрементальний коефріцієнт «витрати-ефективність»;

Cost, Cost - витрати на порівнювані діагностичні технології (i, j), у.о.;

$\mathrm{Ef}_{\mathrm{i}}, \mathrm{Ef}_{\mathrm{j}}$ - показники ефективності порівнюваних діагностичних технологій (i, j), од.

3 позиції методу «витрати-ефективність» ФА діагностична технологія може бути визнана:

- «суворо кращою» в тому випадку, якщо вона демонструє кращу ефективність при більш низьких витратах, тобто характеризується меншим значенням коефріцієнта «витрати-ефективність» і економією коштів перед іншими порівнюваними технологіями;

- «затратно-есрективною» у разі, коли діагностична технологія при більш низькому значенні коефіцієнта «витрати-ефективність» передбачає витрачання додаткових коштів у порівнянні з іншими альтернативами, але демонструє кращу діагностичну ефективність або навпаки;
- «неефективною» - у разі, якщо діагностична технологія має більше значення коефіцієнта «витратиесрективність» при меншій діагностичній ефективності.

Метод ФА «витрати-ефективність» досить часто використовують у комбінації з методами математичного моделювання. В якості такого інструменту до вибору оптимального варіанту при наявності неповної або недостатньо достовірної клініко-лабораторної інорормації використовується підхід, заснований на побудові ймовірнісної математичної моделі - «дерева прийняття рішень». Гілки дерева відображають альтернативи стратегічного вибору (схеми діагностики) з вірогідністю настання подій і кінцевим результатом (витратами на кожну діагностичну технологію і її ефективністю) $[19,20]$.

В основу аналізу можуть бути покладені розроблені або існуючі відповідно до сучасних протоколів алгоритми діагностики вірусних інфекцій, що дозволяють проаналізувати діагностичні стратегії застосування різних технологій, наприклад, швидких тестів на основі імунохроматографрічного аналізу (IXA) і молекулярнобіологічних технологій [21-23]. У цьому випадку в ФА можуть бути розглянуті стратегії застосування тільки першого (стратегія (i)) або тільки другого методу діагностики (стратегія (j)). Використання комбінованої стратегії (i+j) обґрунтовується необхідністю верифрікації негативного результату, оскільки отримання негативних результатів при їх використанні не виключає можливого інфікування у зв'язку 3 недостатньою чутливістю швидких тестів. Кожна аналітична модель або дерево рішень, представляє конкретну стратегію етіологічної діагностики і має гілки, що відображають діагностичні статуси пацієнтів (позитивний, хибнопозитивний, негативний і хибнонегативний). За умови хибнопозитивного або хибнонегативного діагностичного статусу пацієнта діагностична ефрективність стратегії прирівнюється до нуля.

Для кожної пари методів діагностики існує п'ять варіантів порівняння їх діагностичних спектрів $P_{i}$ i $P_{j}$ в разі вибору комбінованої стратегії (i+j) (мал. 2).

Для оцінки стратегій (i) і (j) вид аналітичної моделі буде однаковим.

Для оцінки комбінованої стратегії (i + j) вид аналітичної моделі залежатиме від діагностичних спектрів обох тест-систем (рис. 1) і може мати п'ять варіантів розрахунку.

Після вибору і побудови відповідної аналітичної моделі на їі основі роблять необхідні розрахунки середньозважених значень витрат і есрективності, а також коефріцієнтів CER і $\triangle \mathrm{CER}$. Так, наприклад, для стратегії (i) розрахунок витрат та ефективності проводиться за фрормулою (6): 


$$
\begin{aligned}
& \overline{\operatorname{Cost}_{i}}=P_{i} \times S_{i} \times \operatorname{Cost}_{i}+\left(1-P_{i}\right) \times\left(1-S p_{i}\right) \times \operatorname{Cost}_{i}+\left(1-P_{i}\right) \times S p_{i} \times \operatorname{Cost}_{i} \times P_{i}+\left(1-S_{i}\right) \times \operatorname{Cost}_{i} \\
& \overline{E f_{i}}=P_{i} \times S_{i} \times E f_{i}+\left(1-P_{i}\right) \times\left(1-S p_{i}\right) \times 0+\left(1-P_{i}\right) \times S p_{i} \times E f_{i} \times P_{i} \times\left(1-S_{i}\right) \times 0=P_{i} \times S_{i} \times E f_{i}+\left(1-P_{i}\right) \times S p_{i} \times E f_{i}
\end{aligned}
$$

a)

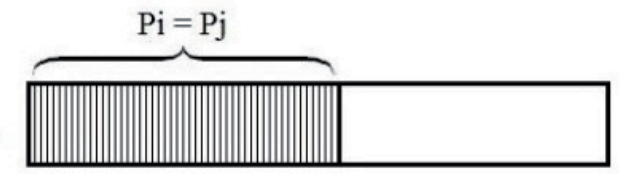

б)

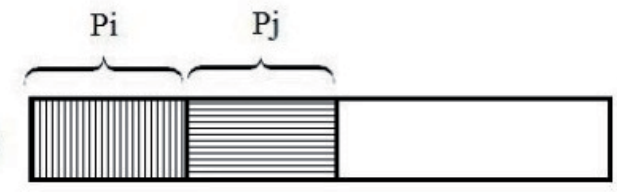

в)

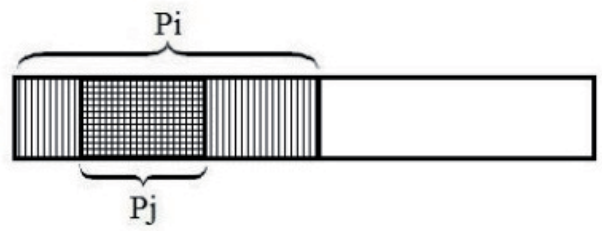

г)

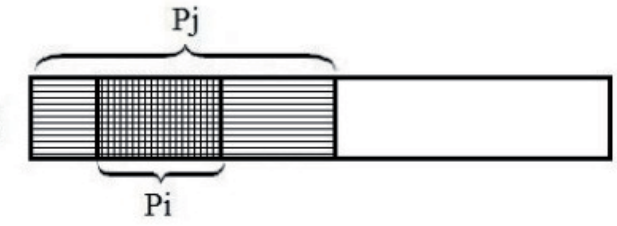

$\mathrm{Pi}$

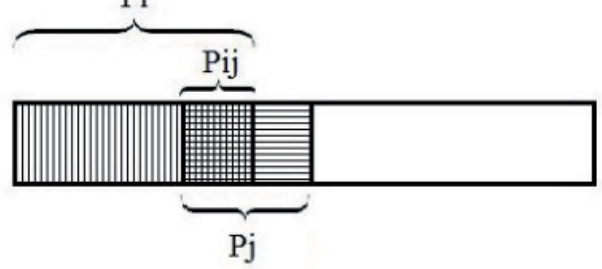

Мал. 2. Варіанти порівняння діагностичних спектрів при комбінуванні методів діагностики (i, j).

Розрахунок коефріцієнтів CER i $\triangle$ CER проводиться за фрормулами (1-2) на основі отриманих середньозважених значень витрат і ефективності. Для моделей іншого виду розрахунки проводяться аналогічно (1-3).

Від теорії до практики: приклад проведення ФА

Прикладом використання розробленої методології ФА може стати аналіз стратегій діагностики гострих вірусних інфекцій, етіологічним агентом яких $€$ респіраторні віруси. За ретроспективними даними в осінньо-зимовий період 2009-2010 рр. під час розвитку пандемії вірусу грипу A/California/7/2009 (H1N1) нами були досліджені клінічні зразки (носоглоткові змиви і харкотиння) від 112 хворих віком від 19 до 25 років 3 негоспітальними пневмоніями (НП). Для виявлення та ідентифрікації респіраторних вірусів були застосовані швидкі тести та молекулярно-генетичні технології на основі ПЛР [18, 19]. Результати дослідження представлені в табл. 3.

Таблиця 3

Спектр респіраторних вірусів серед хворих з НП

\begin{tabular}{|l|c|c|}
\hline \multicolumn{1}{|c|}{ Збудник } & $\begin{array}{c}\text { Позитивний } \\
\text { результат } \\
\text { (абсолютна } \\
\text { кількість) }\end{array}$ & $\begin{array}{c}\text { Позитивний } \\
\text { результат, \% }\end{array}$ \\
\hline Adenovirus & 5 & 4,46 \\
\hline Metapneumovirus & 0 & 0 \\
\hline Parainfluenza virus 1 & 10 & 8,9 \\
\hline Parainfluenza virus 2 & 12 & 10,0 \\
\hline Parainfluenza virus 3 & 10 & 8,9 \\
\hline Influenza A virus & 34 & 30,3 \\
\hline Influenza B virus & 0 & 0 \\
\hline $\begin{array}{l}\text { Respiratory syncytial (RS) } \\
\text { virus B }\end{array}$ & 4 & 3,5 \\
\hline $\begin{array}{l}\text { Respiratory syncytial (RS) } \\
\text { virus A }\end{array}$ & 9 & 8,0 \\
\hline Rinovirus A/B & 2 & 1,7 \\
\hline Coronavirus OC43/HKU1 & 1 & 0,9 \\
\hline Coronavirus 229E/NL63 & 8 & 7,1 \\
\hline He iдентифріковано & 17 & 15,2 \\
\hline Bсього & 112 & 100,0 \\
\hline
\end{tabular}

Враховуючи те, що в Україні широко застосовуються IXA-тести на виявлення вірусу грипу A+B, респіраторних аденовірусів і РС-вірусів, стратегії були розраховані на прикладі виявлення респіраторних аденовірусів. Розглянуто три стратегії вибору: застосування швидких IXА-тестів на один збудник (стратегія № 1), мультиплексної ПлР на 12 респіраторних вірусів, серед яких один може бути виявлений IXA-тестами (стратегія № 2). Включення в одну стратегію послідовно пари методів досліджень обґрунтовувалося необхідністю розширити діагностичний спектр і врахувати можливості ко-інфікування двома і більше вірусами (стратегія № 3 як комбінація стратегій № 1 і № 2).

Вартість кожної діагностичної стратегії оцінювалася на основі середніх каталожних цін на послуги, що пропонуються діагностичними центрами у м. Києві та Чернігові (табл. 4). 
Таблиця 4

Порівнювані діагностичні стратегії та їх параметри

\begin{tabular}{|c|c|c|}
\hline $\begin{array}{c}\text { Діагностична стратегія №1 } \\
\text { (тільки IXА-тести) }\end{array}$ & $\begin{array}{c}\text { Діагностична стратегія №2 } \\
\text { (тільки ПЛР-метод) }\end{array}$ & $\begin{array}{c}\text { Порівняння } \\
\text { діагностичних } \\
\text { спектрів } \mathrm{P}_{1} \text { та } \mathrm{P}_{2}\end{array}$ \\
\hline $\begin{array}{l}\text { - Чутливість - } 85 \text { \% } \\
\text { - Специорічність - } 95 \text { \% } \\
\text { - Діагностичний спектр (ДС) - 4,46 \% } \\
\text { (аденовіруси) } \\
\text { - Вартість - } 60 \text { грн. } \\
\text { - Ефрективність - } 1 \text { од. }\end{array}$ & $\begin{array}{l}\text { - Діагностичний спектр - 84,8 \% (аденовіруси, метапневмові- } \\
\text { рус, віруси парагрипу 1, віруси парагрипу 2, віруси парагрипу } \\
\text { 3, віруси грипу А, віруси грипу В, респіраторно-синцитіальні } \\
\text { віруси А, респіраторно-синцитіальні віруси В, риновіруси A/B, } \\
\text { коронавіруси ОС43/HKU1, коронавіруси 229E/NL63) } \\
\text { - Вартість - } 400 \text { грн. } \\
\text { - Ефрективність - } 12 \text { од. }\end{array}$ & $\mathrm{P}_{1}$ входить в $\mathrm{P}_{2}$ \\
\hline
\end{tabular}

Першим етапом ФА досліджень стало проведення однофакторного аналізу рентабельності кожної із запропонованих стратегій залежно від зміни діагностичного спектру циркулюючих вірусів. Після завершення вводу вихідних параметрів для кожної з досліджуваних стратегій в комп'ютерну програму було отримано таблицю даних, яка передбачала можливість видалення певної діагностичної стратегії чи корекцію даних.

Реалізація ФА за допомогою комп'ютерної програми показала, що за умови високої чутливості і специфріч- ності тестів (більше 80 \%) діагностична стратегія № 2 (метод мультиплексної ПлР для виявлення 12 збудників) $€$ затратно-ефективною, а її впровадження дозволяє знизити витрати на одиницю діагностичної ефективності (один виявлений збудник) в середньому на $45 \%$ порівняно 3 діагностичною стратегією 1 , а впровадження діагностичної стратегії 3 порівняно 3 діагностичною стратегією №1 - в середньому на 36,2 \% (мал. 3).

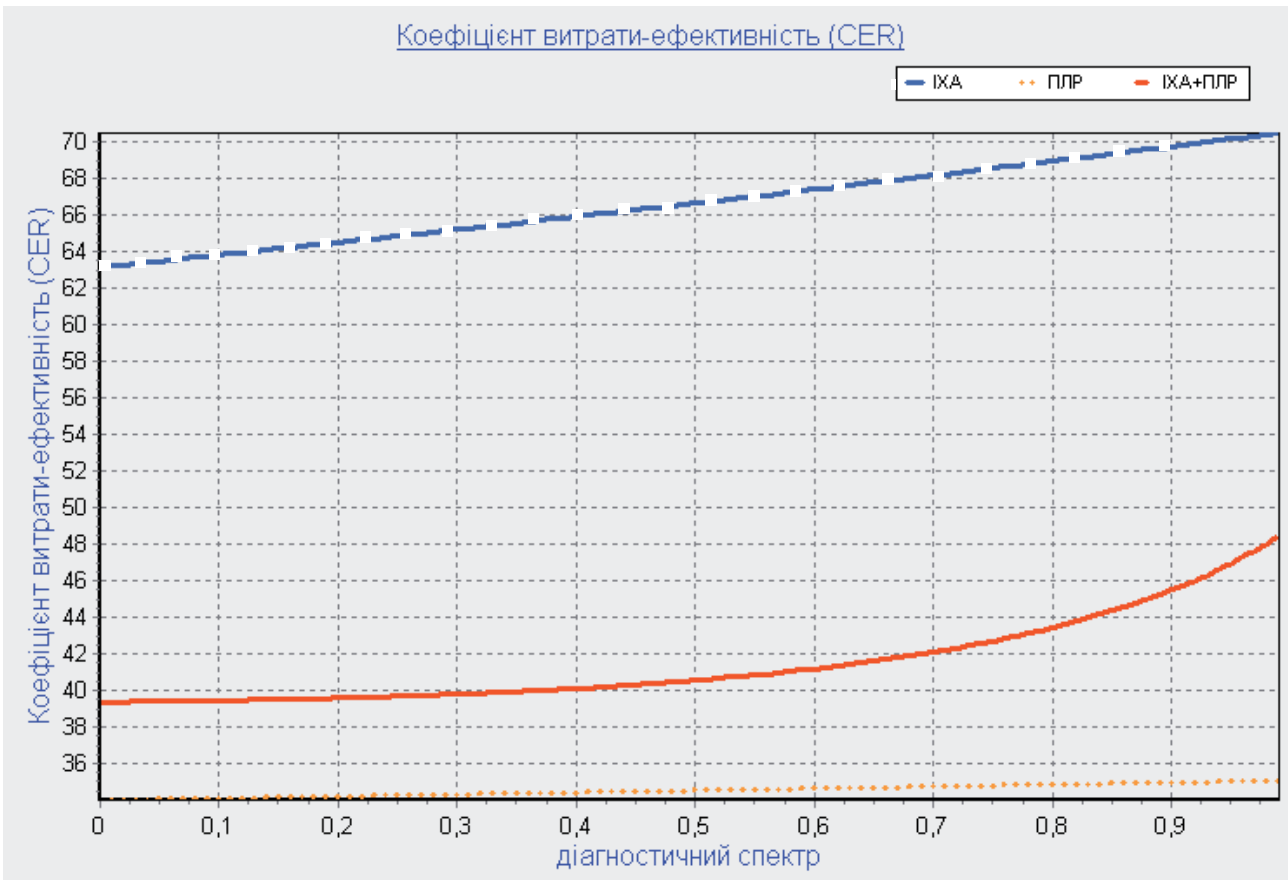

Мал. 3. Аналіз залежності коефріцієнта CER від діагностичного спектру збудників.

Дослідження залежності аналітичної моделі від зміни етіологічного спектра респіраторних вірусів дозволило виявити максимальний економічний ефект стратегії 3 порівняно зі стратегією №1 - в середньому 37,9 \% при значному рівні діагностичного спектру IXAтестів (85-100 \%) (мал. 4).
Результати проведення багатофакторного аналізу представлені на мал. 5-7. Вони свідчать, що навіть за умови широкого діапазону невизначеності параметрів, стратегія № $2 €$ затратно-ефективною порівняно зі стратегією № 1 та № 1+№ 2. 


\section{ОГЛЯДИ ТА ЛЕКЦІї}

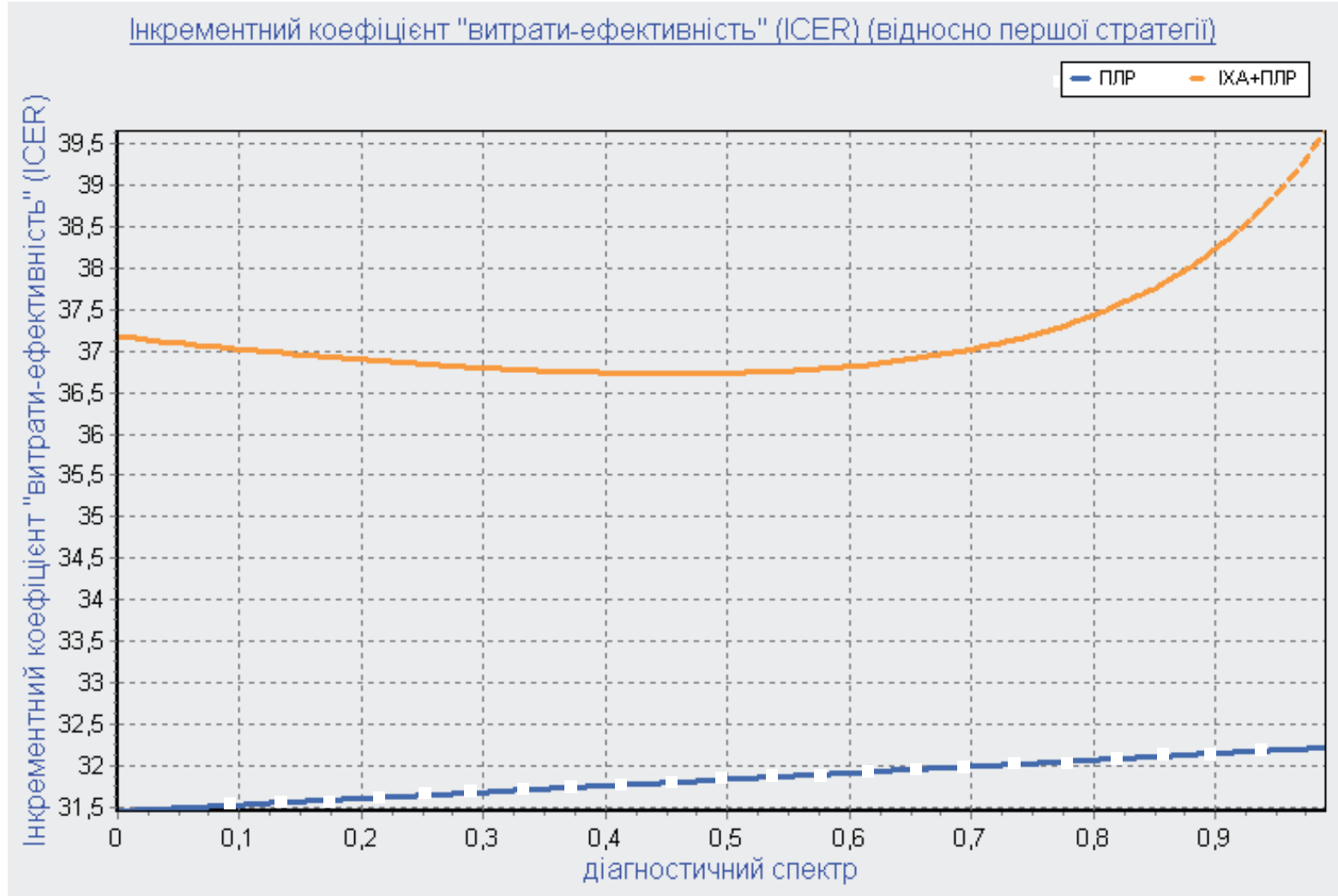

Мал. 4. Аналіз залежності коефіцієнта $\triangle \mathrm{CER}$ від діагностичного спектру збудників.

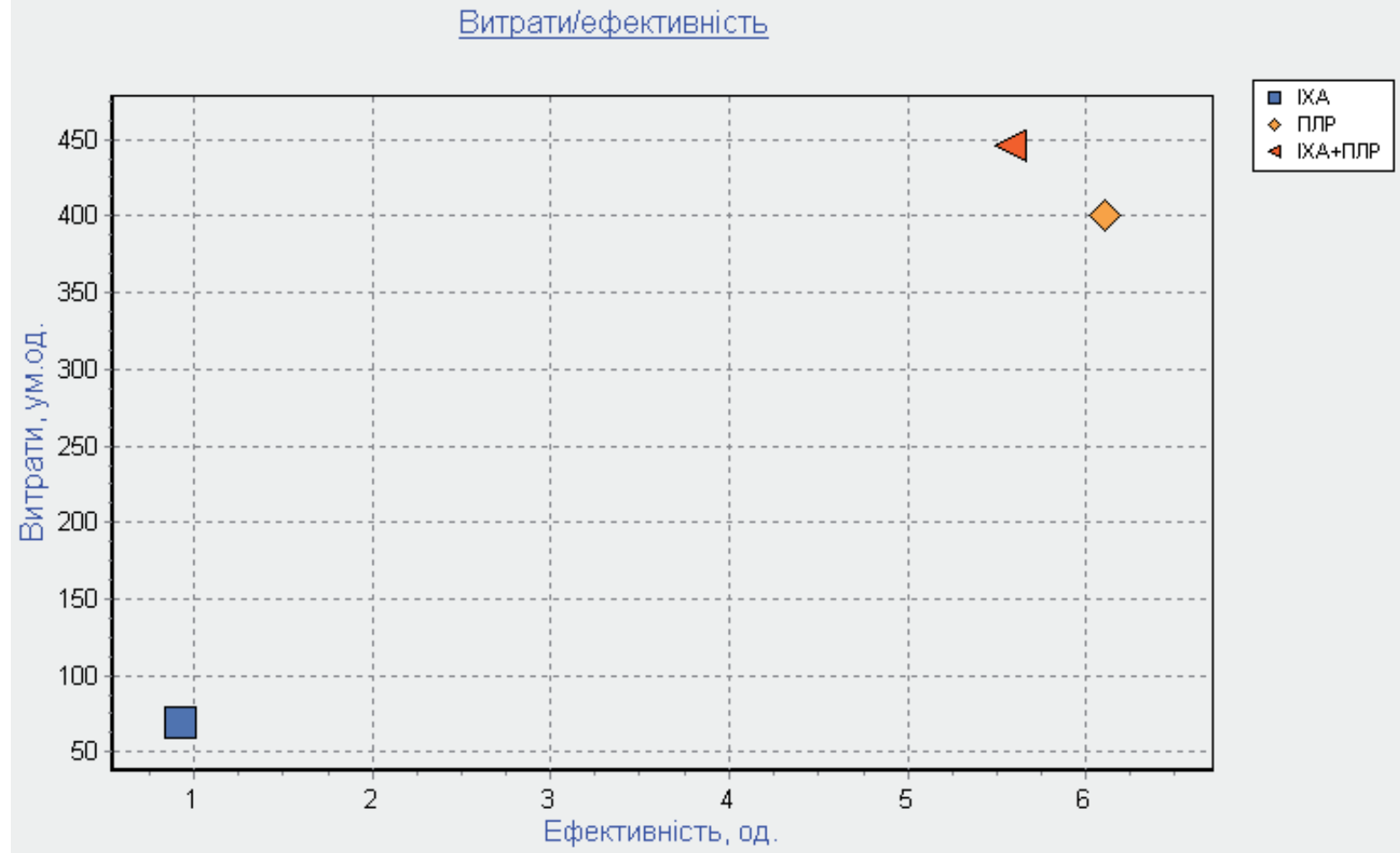

Мал. 5. Відношення витрат до ефективності кожної діагностичної стратегії (багатофракторний аналіз). 


\section{ОГЛЯДИ ТА ЛЕКЦІї}

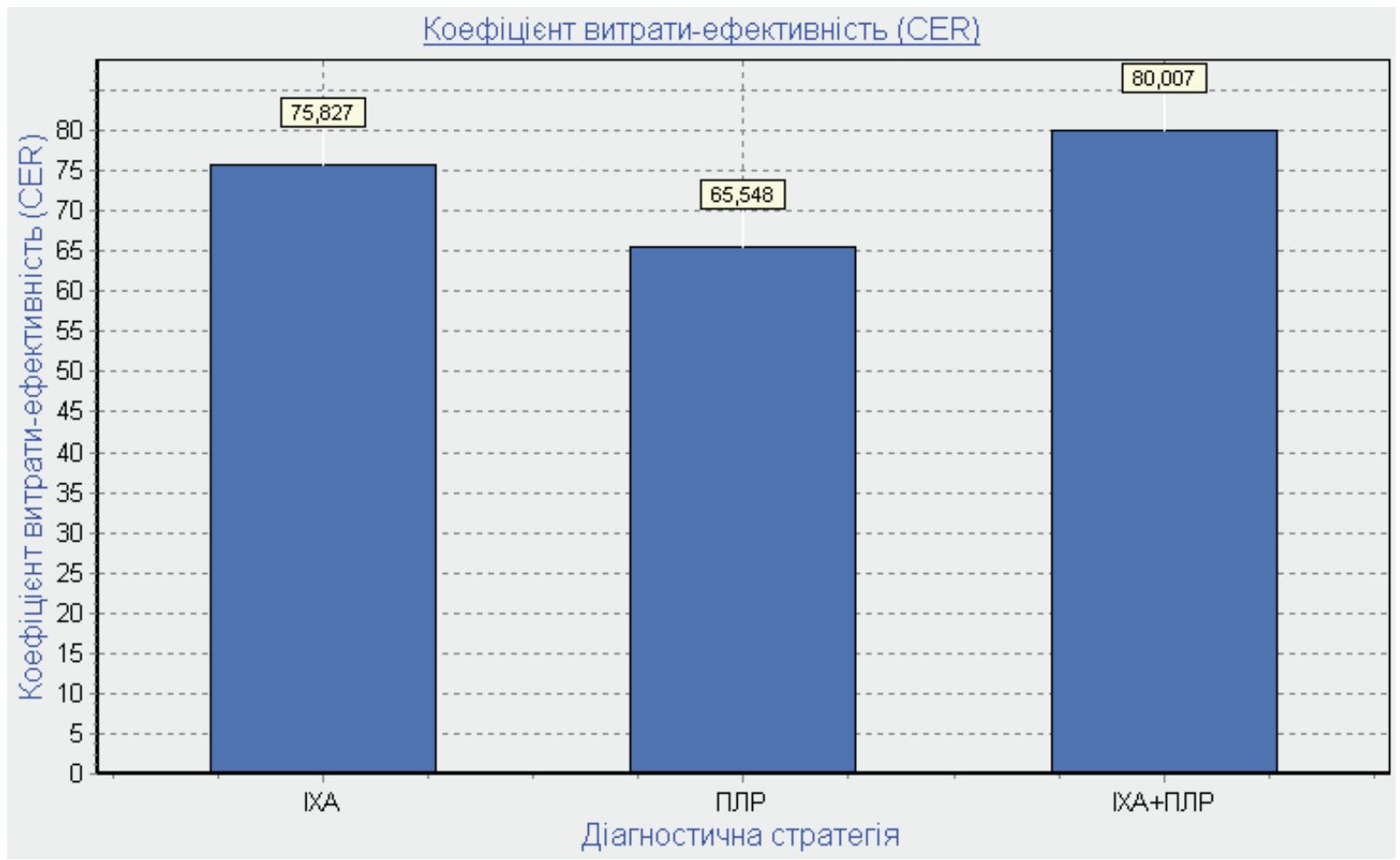

Мал. 6. Середнє значення коефіцієнта CER (багатофракторний аналіз).

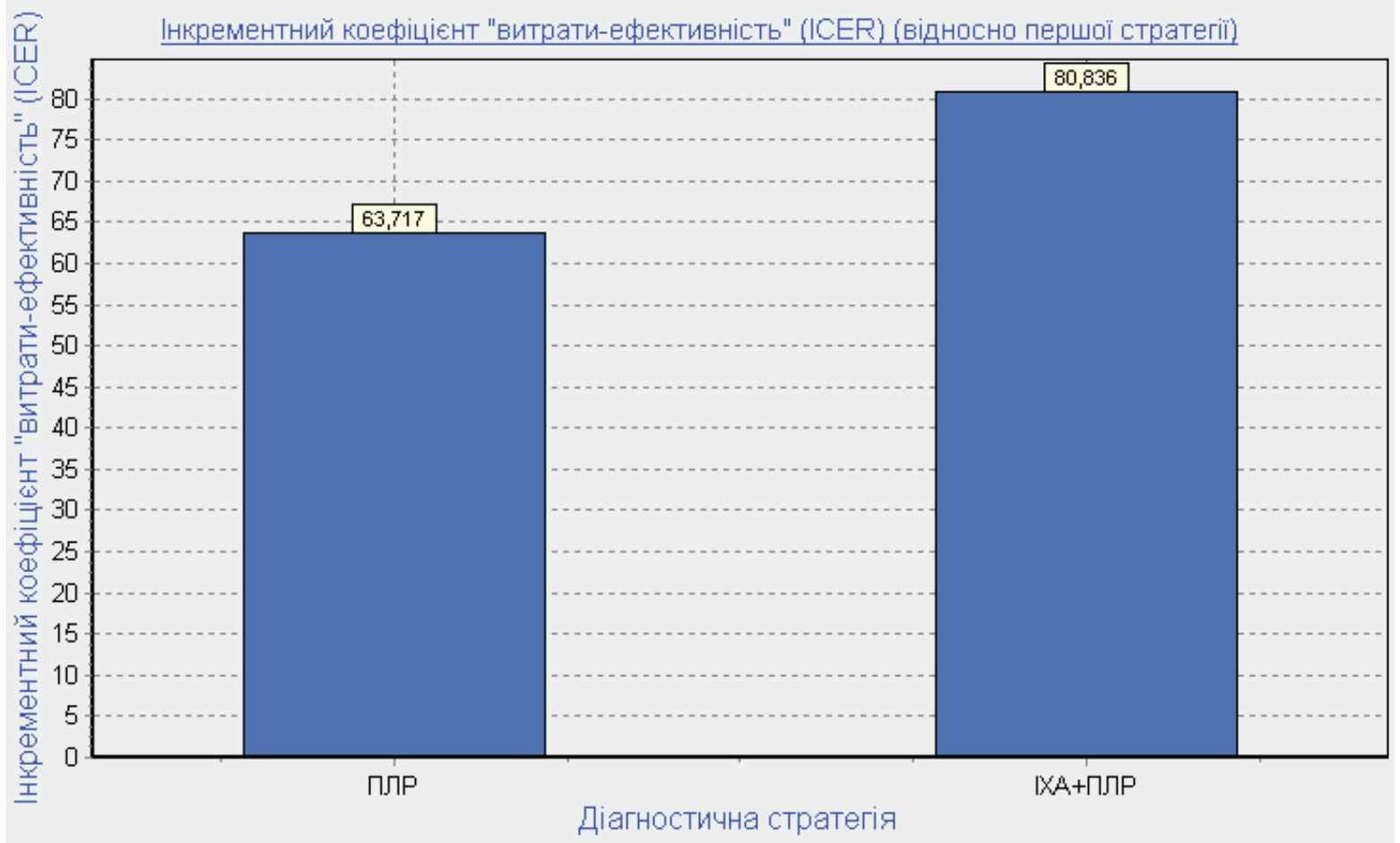

Мал. 7. Середнє значення коефріцієнта $\triangle \mathrm{CER}$ (багатофракторний аналіз).

\section{Висновок}

У даній роботі ми зупинились на фрармакоекономічній оцінці стратегій діагностики гострих вірусних інфрекцій, оскільки така оцінка значно відрізняється від оцінки стратегій діагностики хронічних вірусних інфекцій (діагностичного скринінгу). Наведено теоретичні основи 
та основні поняття, що використовуються в ФА стратегій діагностики гострих вірусних інфекцій людини. Запропоновано науково обґрунтовану методологію проведення ФА на основі методу «витрати-ефективність» 3 використанням методів математичного моделювання, що дозволяє оцінювати раціональність вибору діагностичної стратегії для виявлення вірусів на основі запропонованої методології за методом «витрати - ефективність». Особливістю методу є те, що при розрахунках беруться до уваги чутливість і специфічність діагностичних тестів й тест-систем, їх діагностичний спектр, витрати на діагностику та діагностична ефективність. Запропонований приклад проведення такого аналізу для гострих респіраторних інсрекцій на основі розробленої комп'ютерної програми «Фармакоекономічний аналіз стратегій діагностики респіраторних вірусних інфрекцій», що ґрунтується на описаній методології.

\section{Література}

1. Bleuler E. Das autistisch-undisziplinierte Denken in der Medizin und seine Uberwindung / E. Bleuler. - Berlin: Springer, 1919.

2. Белоусов Ю.Б. Основы фрармакоэкономических исследований / Ю.Б. Белоусов, Д.Ю. Белоусов, В.П. Комарова. - М.: ООО «Издательство ОКИ», июнь 2000 г. - 87 с.

3. Клинико-экономический анализ / [П.А. Воробьев, М.В. Авксентьева, О.В. Борисенко и др.]. - 3-е изд., дополн. - М.: Ньюдиамед, 2008. - 778 c.

4. Cost analysis of multiplex PCR testing for diagnosing respiratory virus infections / [J.B. Mahony, G. Blackhouse, J. Babwah et al.] // J. Clin. Microbiol. - 2009. - Vol. 47, N 9. - P. 2812-2817.

5. Cost-effectiveness of malaria diagnostic methods in subSaharan Africa in an era of combination therapy / [S. Shillcutt, C. Morel, C. Goodman et al.] // Bull. World Health Organ. - 2008. - Vol. 86. P. 101-110.

6. Гайковая Л.Б. Экономическое обоснование целесообразности использования метода проточной цитометрии для оценки фрункциональной активности тромбоцитов у пациентов, получающих антиагрегантные препараты / Л.Б. Гайковая, Т.В. Вавилова, О.В. Сироткина // Справочник заведующего КДЛ. - 2013. - № 8. - С. 73-79.

7. Ягудина Р.И. Фармакоэкономическое исследование лекарственных средств для диагностики туберкулезной инсрекции / Р.И. Ягудина, И.Ю. Зинчук // Фармакоэкономика. - 2013. - Т. 6. , № 1. - C. 11-15.

8. Фармакоэкономический анализ для оценки стратегий диагностики респираторных вирусных инфекций / С.А. Соловьев, Я.А. Дзюблик, О.В. Обертинская, И.В. Дзюблик // Рецепт. - 2014. - № 6. - С. 119-128.

9. Мікробіологія, вірусологія та імунологія: підручник для ВМН3 III-IV р.а. / Під ред. Широбокова В.П. - Вінниця: Нова Книга, 2011. $-952 \mathrm{c}$.

10. Заліська О.М. Фармакоекономіка: теорія і практика / О.М. Заліська // Фармацевт. журнал. - 2000. - № 2. - С. 10-16.

11. Заліська О.М. Програма фрармакоекономічної оцінки лікарських засобів / О.М. Заліська, Б.Л. Парновський // Реєстр галузевих нововведень МОЗ України. - 2002. - № 16-17. - С. 105-106.

12. Заліська О.М. Фармакоекономіка: теоретичні й практичні напрями у світі та в Україні / О.М. Заліська, Б.Л. Парновський // Рациональная фармакотерапія. - 2010. - № 4 (17). - С. 14-17.
13. Use of Pharmacoeconomics Information Report of the ISPOR Task Force on Use of Pharmacoeconomic / [M. Drummond, R. Brown, A.M. Fendrick et al.] // Health Economic Information in Health-Care Decision Making. Value in Health. - 2003. - Vol. 6, N 4. - P. 407-415.

14. Health care cost, quality and outcomes. ISPOR Terms Book / Ed. M.L. Berger, K. Bingefors, E.C. Hedblom et al. - 2003. - 264 p.

15. Mayrhofer T. Medical Decision Making / T. Mayrhofer, St. Felder. - Springer, 2011.

16. CookA.G. Forecasting for the pharmaceutical industry: models for new product and in-market forecasting and how to use them I A.G. Cook. - Gower Publishing Limited, 2006. - 141 p.

17. Гнеденко Б.В. Курс теории вероятностей / Б.В. Гнеденко. - 6-е изд. - М.: Наука, 1988. - 446 с.

18. Von Neumann J. Theory of games and economic behavior / J. von Neumann, O. Morgenstern. - 2nd ed. - Princeton: Princeton University Press, 1947.

19. Roberts M.S. Decision Modeling Techniques / M.S. Roberts, K.J. Smith // Pharmacoeconomics: from theory to practice / Ed. by R.J.G. Arnold. - Boca Raton: CRC Press (Taylor and Francis Group, LLC), 2010. - P. 37-46.

20. Пастухов Н.В. Проектирование инорормационной системы лекарственного обеспечения учреждений здравоохранения / Н.В. Пастухов, И.В. Спичак // Человек и его здоровье. - 2005. №3. - C. 73-79.

21. Дзюблик Я.О. Алгоритм етіологічної діагностики негоспітальних інфекцій нижніх дихальних шляхів / Я.О. Дзюблик, О.В. Обертинська // Укр. пульмонол. журнал. - 2013. - №3 (Додаток). - С. 112-113.

22. Швидкі IXА-тести для етіологічної діагностики інфекційних захворювань людини: Метод. рекомендації / [І.В. Дзюблик, О.В. Обертинська, Я.О. Дзюблик та ін.]. - К., 2013. - 24 с.

23. Полімеразна ланцюгова реакція в лабораторній діагностиці інсекційних хвороб: навч.-метод. посібник для лікарів /за ред. І.В. Дзюблик, Н.Г. Горовенко. - К., 2012. - 219 с.

\section{PHARMACOECONOMIC ANALYSIS OF DIAGNOSIS STRATEGIES OF ACUTE VIRAL INFECTIONS: OPERATING CHARACTERISTICS, METHODS OF ASSESSMENT AND CASE STUDY}

\author{
S.O. Solovyov, I.V. Dzyublyk
}

SUMMARY. The paper presents scientific approach to the assessment of diagnostic strategies of acute viral infections, based on the principles of pharmacoeconomic science. For the first time the basic concepts, operational characteristics used in such analysis, and case study of its use in medical practice were shown. The possibility of implementing such analysis into the work of organizers and experts of healthcare, physicians and heads of medical laboratories will improve the effectiveness of any laboratory department or laboratories of different ownership.

Key words: acute viral infection, diagnostic strategy, pharmacoeconomics, "cost-effectiveness" method, analytical model.

Отримано 15.12.2015 p. 